\title{
Sensitivity to the Anorectic Effects of Leptin Is Retained in Rats Maintained on a Ketogenic Diet despite Increased Adiposity
}

\author{
Kimberly P. Kinzig ${ }^{a} \quad$ Mary Ann Honors $^{a}$ Sara L. Hargrave ${ }^{a}$ \\ Brandon M. Davenport ${ }^{a}$ April D. Strader ${ }^{b}$ Donna Wendt ${ }^{b}$ \\ a Department of Psychological Sciences and Ingestive Behavior Research Center, Purdue University,

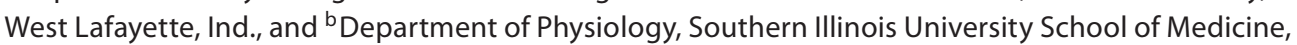 \\ Carbondale, III., USA
}

\section{Key Words}

Energy balance $\cdot$ Leptin $\cdot$ Arcuate nucleus $\cdot$ Obesity

\begin{abstract}
Background: Rats maintained on a ketogenic diet (KD; 80\% fat, $15 \%$ protein, $5 \%$ carbohydrate) have increased adiposity and leptin as compared to chow-fed controls $(\mathrm{CH} ; 16 \%$ fat, $19 \%$ protein, $65 \%$ carbohydrate), although body weights and daily caloric intakes do not differ. Methods: Rats maintained on a $\mathrm{KD}$ or $\mathrm{CH}$ were assessed for responsivity to intraperitoneal (i.p.) or intracerebroventricular (i.c.v.) leptin. Hypothalamic gene expression was evaluated to determine the effects of KD on proopiomelanocortin (POMC) mRNA expression and components of the leptin-signaling system. Results: Caloric intake by KD rats was decreased at a lower dose of i.p. leptin $(100 \mu \mathrm{g})$ than was required to reduce intake by $\mathrm{CH}$ rats (leptin, caloric intake was reduced in KD rats as compared to intake following i.p. saline; $p<0.05$ ). In a separate experiment to evaluate responsivity to i.c.v. leptin, the minimal dose of leptin required to significantly reduce 24 hour caloric intake did not differ between the groups. In the arcuate nucleus, POMC mRNA was elevated after a lower dose of i.c.v. leptin in $\mathrm{KD}$ rats $(5 \mu \mathrm{g})$ than was required to increase POMC mRNA expression in $\mathrm{CH}$ rats $(15 \mu \mathrm{g})$ or reduce caloric intake in either group. Finally, evaluation of the level
\end{abstract}

of phosphorylated STAT3 (pSTAT3) in the arcuate and SOCS3 mRNA in the hypothalamus revealed significantly more pSTAT3-positive cells and increased SOCS3 mRNA expression at baseline for KD rats, compared to $\mathrm{CH}$, neither of which was further increased following i.p. leptin administration. Conclusion: These data demonstrate that despite increased adiposity, leptin and markers of leptin resistance, responsivity to the anorectic effects of exogenous leptin is retainable during maintenance on a KD.

Copyright $\odot 2010$ S. Karger AG, Basel

\section{Introduction}

Energy balance is mediated by multiple, complex systems that act in concert to control food intake and regulate body weight. One important regulator of energy balance is the adiposity hormone leptin. Leptin is secreted in proportion to fat mass such that levels of circulating leptin correlate with body adiposity [1-3]. Accordingly, leptin levels are elevated in obese individuals and de-

This research was supported by NIH R01DK078654. The content is solely the responsibility of the authors and does not necessarily represent the official views of NIDDK or the National Institutes of Health.

\section{KARGER}

Fax +41613061234

E-Mail karger@karger.ch

www.karger.com (c) 2010 S. Karger AG, Basel

Accessible online at: www.karger.com/nen
Kimberly Kinzig

Department of Psychological Sciences and Ingestive Behavior Research Center Purdue University, 703 Third Street

West Lafayette, IN 47907 (USA)

Tel. +1 765496 8220, Fax +1 765496 1264, E-Mail kkinzig@ @urdue.edu 
creased after weight loss or fasting. Both central and peripheral administration of leptin reduces food intake, increases energy expenditure, and limits adiposity [4-6].

Many of the actions of leptin are due to its actions in the hypothalamus $[7,8]$. Leptin enters the brain through a saturable transport process [9], and activation of the long form of the leptin receptor (Ob-Rb) has been demonstrated to mediate its physiological actions [10-13]. Leptin receptors are expressed in many areas of the brain, and one location important to the regulation of food intake is in the arcuate nucleus on neuropeptide Y (NPY) and proopiomelanocortin (POMC) neurons [14-16]. In lean rodents, exogenous administration of leptin suppresses NPY mRNA expression and stimulates POMC mRNA expression [17-20]. In the brain, leptin induces the Janus kinase signal transducer and activator of transcription (JAK-STAT) tyrosine kinases and activates signal transducer and activator 3 (STAT3). STAT3 activates the transcription of POMC as well as the signaling inhibitor suppressor of cytokine signaling 3 (SOCS3), which is a negative regulator of the JAK-STAT signaling pathway $[21,22]$.

Diet-induced obese (DIO) animals become resistant to the anorectic effects of leptin [23-26]. Two hypotheses of the mechanisms underlying leptin resistance have garnered a great deal of attention. One hypothesis is that peripheral leptin becomes unable to reach its targets in the brain due to saturation of the system responsible for transporting leptin across the blood brain barrier (BBB), such that the ratio of peripherally circulating leptin to levels of leptin in the cerebrospinal fluid is reduced [27, 28]. Resistance to peripherally administered leptin occurs shortly after the start of high-fat diet exposure, when sensitivity to leptin delivered into the CNS remains [29]. A second hypothesis is that leptin resistance is attributable to defects in CNS pathways/neurons that mediate leptin's actions [for review, see 30]. It has been demonstrated that diet-induced obesity, concomitant with increased circulating leptin levels, inhibits the ability of leptin to activate hypothalamic signaling [24, 31-34]. As part of the leptin-signaling cascade, SOCS3 is stimulated and acts to inhibit Ob-Rb signaling [24, 30, 35]. Leptin resistance is associated with elevated SOCS3 levels in the arcuate in response to high-fat diet feeding, and increased activity of SOCS3 may be a potential mechanism for leptin resistance $[24,36]$. Studies in mice have demonstrated a relationship between SOCS3 and the CNS melanocortin system. Leptin induces a greater increase in POMC expression in SOCS3-deficient mice than in wildtype mice [37].

Leptin Sensitivity and the Ketogenic Diet
We have previously demonstrated that maintenance of rats on a ketogenic diet (KD) alters the behavioral, endocrine and hypothalamic factors involved in the regulation of energy balance, when compared to rats maintained on diets that do not induce ketosis. Rats maintained on a KD consume the same number of kilocalories per day and have similar body weights to chow-fed controls $(\mathrm{CH})$. However, maintenance on a $\mathrm{KD}$ results in increased adiposity and correspondingly high levels of plasma leptin, although insulin levels are suppressed. Moreover, the KD affects the hypothalamic melanocortin system such that KD rats are more responsive to the anorectic effects of MTII, have less POMC mRNA expression in the arcuate nucleus and elevated MC4R mRNA in the paraventricular nucleus as compared to rats maintained on $\mathrm{CH}$ [38].

Because obesity and increased adiposity in rats maintained on high-fat non-KDs are associated with leptin resistance, our current experiments sought to determine whether maintenance on a KD affected responsivity to the anorectic effects of leptin and leptin signaling within the hypothalamus. Rats were maintained on $\mathrm{CH}$ or $\mathrm{KD}$ for 4 weeks. Responsivity to the anorectic effects of intraperitoneal (i.p.) and intracerebroventricular (i.c.v.) leptin was assessed, as were the effects of administration of peripheral and central leptin on levels of hypothalamic POMC mRNA. Furthermore, the level of phosphorylation of STAT3 in the arcuate nucleus and the expression of SOCS3 and Ob-Rb mRNA in the hypothalamus were measured to determine whether these factors were affected by maintenance on a KD under basal or leptin-stimulated conditions.

\section{Methods}

\section{Animals and Diets}

Male Long Evans rats (Harlan, Indianapolis, Ind., USA) weighing 250-300 g were individually housed in stainless steel hanging wire cages and maintained at a constant temperature $\left(25^{\circ} \mathrm{C}\right)$ on a $12: 12 \mathrm{~h}$ light/dark cycle (lights on at 4:00 a.m.). All rats had 24-hour access to food and tap water during all portions of the experiment, except where noted. After 1 week of acclimation to the laboratory, during which time rats were given ad libitum access to rodent chow (CH; $3.3 \mathrm{kcal} / \mathrm{g}$; Harlan Teklad 2018), rats were weight-matched and divided into 2 separate diet groups. In each experiment, 1 group of rats was maintained on $\mathrm{CH}$, and the other was maintained on a low-carbohydrate KD $(6.1 \mathrm{kcal} / \mathrm{g}$; Research Diets D06040601, Research Diets Inc., New Brunswick, N.J., USA; table 1). Caloric intake and body weights were measured and recorded daily. All procedures were approved by the Purdue University Animal Care and Use Committee. 
Experiment 1A: Responsivity to the Anorectic Effects of Peripherally Administered Leptin in Rats Maintained on a Low-Carbohydrate KD

Following 4 weeks of maintenance on $\mathrm{CH}(\mathrm{n}=9)$ or $\mathrm{KD}(\mathrm{n}=$ 11), rats were subjected to a series of i.p. injections to determine the effectiveness of peripheral leptin to reduce caloric intake. All rats were injected i.p. with the vehicle (physiological saline, $1 \mathrm{ml}$ ) and 2 doses of leptin (100 and $200 \mu \mathrm{g}$; CalBiochem, San Diego, Calif., USA) in a counterbalanced manner, with no less than 5 days between injections. On test days, food was removed $1 \mathrm{~h}$ prior to injection. Rats were injected $30 \mathrm{~min}$ prior to the onset of the dark cycle, at which time food was replaced in the cage. Intake was measured 4 and $24 \mathrm{~h}$ later, and spillage was collected at each time point to ensure accurate intake measures.

\section{Experiment 1B: Responsivity to the Anorectic Effects of}

Peripherally Administered Leptin in Rats Maintained on $\mathrm{CH}$

Based on the results of experiment $1 \mathrm{~A}$, an additional group of rats was maintained on $\mathrm{CH}(\mathrm{n}=8)$ for 4 weeks as described above. Rats were then given an i.p. injection of saline and $2 \mathrm{mg} / \mathrm{kg}$ leptin in a counterbalanced manner, with at least 5 days between injections. Food intake was recorded 4 and $24 \mathrm{~h}$ after injection, and spillage was collected as described above.

\section{Experiment 2: Responsivity to the Anorectic Effects of Centrally Administered Leptin in Rats Maintained on a Low-Carbohydrate KD}

After 4 weeks on $\mathrm{CH}(\mathrm{n}=12)$ or $\mathrm{KD}(\mathrm{n}=9)$, rats were stereotaxically implanted with cannulas aimed at the lateral cerebral ventricle. Briefly, rats were anesthetized with $1 \mathrm{ml} / \mathrm{kg}$ of a $4 / 3$ mixture of ketamine $(100 \mathrm{mg} / \mathrm{ml})$ and xylazine $(20 \mathrm{mg} / \mathrm{ml})$ and placed into a stereotaxic instrument. A 23-gauge guide cannula (10 $\mathrm{mm}$ in length) was inserted $1.8 \mathrm{~mm}$ posterior to the bregma, $1.6 \mathrm{~mm}$ lateral to the midline (with bregma and lambda at the same vertical coordinate), and $3.3 \mathrm{~mm}$ ventral to the dura [39]. A 30 -gauge, $11.5-\mathrm{mm}$ obturator was placed in the guide cannula. The cannula was secured to the skull with 4 screws and dental acrylic. Following surgery, rats received intramuscular penicillin (60,000 units), an intramuscular injection of the analgesic banamine $(1.1 \mathrm{mg} / \mathrm{kg})$, and $10 \mathrm{ml}$ of saline subcutaneously. Upon recovery of pre-surgical body weight, cannula placement was verified by angiotensin II (AII) testing. All rats drank at least $5 \mathrm{ml}$ more after AII injections ( $5 \mathrm{nmol}$ ) than they drank after i.c.v. saline injection (in $30 \mathrm{~min}$ ) and were therefore deemed to have correct cannula placement.

One week after recovery of pre-surgical body weight, rats began a series of i.c.v. injections to determine the effectiveness of leptin to reduce caloric intake in the 2 dietary groups. A withinsubjects design was used such that rats received i.c.v. injections of physiological saline or leptin (10 and $15 \mu \mathrm{g}$ in $2 \mu \mathrm{l})$. Each rat received saline and both doses of leptin, with not less than 5 days between injections, in a counterbalanced sequence. On test days, food was removed $1 \mathrm{~h}$ prior to injection. Rats were injected $30 \mathrm{~min}$ prior to the onset of the dark cycle, at which time food was replaced in the cage. Intake was measured 4 and $24 \mathrm{~h}$ later.

After continued maintenance on $\mathrm{CH}$ or $\mathrm{KD}$ for 2 weeks following the injection series, rats were sacrificed. On the day of sacrifice, food was removed $8 \mathrm{~h}$ prior to the onset of the dark cycle and rats were rapidly decapitated under ether inhalation anesthesia $6 \mathrm{~h}$ later. Fifty microliters of blood was used to determine the $\beta$-hydroxybutyrate concentration in blood using a StatSite meter (Stanbio Laboratory, Boerne, Tex., USA) and StatSite Blood Ketone Test Cards (Stanbio Laboratory). Levels of $\beta$-hydroxybutyrate in blood were measured as an indication of whether an animal was in a state of ketosis, as $\beta$-hydroxybutyrate is the ketone body produced in the highest amount during ketosis [40]. Trunk blood was collected into chilled $\mathrm{K}^{+}$EDTA vacutainer tubes (Fisher Scientific, Pittsburgh, Pa., USA), briefly placed in ice, and then centrifuged at $4^{\circ} \mathrm{C}$ for $15 \mathrm{~min}$ at 2,000 rpm. Plasma was aspirated into Eppendorf tubes. Plasma was subsequently analyzed for triglyceride and leptin levels. Epididymal, subcutaneous, and retroperitoneal fat pads were also removed and weighed (table 2).

\section{Experiment 3: Effect of Peripheral or Central Leptin}

Administration on Arcuate POMC mRNA Expression

in Rats Maintained on a Low-Carbohydrate KD

To determine the effects of peripheral leptin administration on arcuate POMC mRNA expression in rats maintained on $\mathrm{CH}$ or $\mathrm{KD}$, rats were maintained on $\mathrm{CH}(\mathrm{n}=24)$ or $\mathrm{KD}(\mathrm{n}=16)$ for 4 weeks. Based on the results of experiment 1 and the determination of effective doses of i.p. leptin to reduce food intake in $\mathrm{CH}$ and $\mathrm{KD}$-fed rats, the $\mathrm{CH}$ group was weight-matched and divided such that 1 group received an i.p. injection of saline $(n=8)$, the 2 nd received an i.p. injection of $100 \mu \mathrm{g}$ leptin $(\mathrm{n}=8)$, and the $3 \mathrm{rd}$ received an i.p. injection of $2 \mathrm{mg} / \mathrm{kg}$ leptin $(\mathrm{n}=8)$. For the KD group, saline was given i.p. to 1 group $(\mathrm{n}=8)$ and $100 \mu \mathrm{g}$ leptin was given i.p. to the other $(n=8)$. On injection day, food was removed $6 \mathrm{~h}$ prior to the onset of the dark cycle rats were injected according to group assignment $4 \mathrm{~h}$ later. Food was not replaced and rats were sacrificed $2 \mathrm{~h}$ later by rapid decapitation after exposure to ether. Brains were submerged into iced isopentane for $25 \mathrm{~s}$ and immediately stored in dry ice and then at $-80^{\circ} \mathrm{C}$ until processing.

To evaluate the effects of central leptin administration on arcuate POMC mRNA levels, rats were maintained on $\mathrm{CH}(\mathrm{n}=24)$ or $\mathrm{KD}(\mathrm{n}=24)$ for 4 weeks and implanted with a cannula aimed at the lateral ventricle, as described in experiment 2. Placement was verified by drinking response following AII administration. After recovery of body weight lost due to surgery, rats were weightmatched within dietary groups to form 3 groups per diet. One group was given an i.c.v. injection of $2 \mu \mathrm{l}$ saline, a 2 nd was injected i.c.v. with $5 \mu \mathrm{g}$ leptin in $2 \mu \mathrm{l}$ saline, and the $3 \mathrm{rd}$ was injected i.c.v. with $15 \mu \mathrm{g}$ leptin in $2 \mu \mathrm{l}$ saline. As described for the i.p. leptin experiment above, food was removed $6 \mathrm{~h}$ prior to the onset of the dark cycle and rats were injected with according to group assignment $4 \mathrm{~h}$ later. Food was not replaced and rats were sacrificed $2 \mathrm{~h}$ later by rapid decapitation after exposure to ether. Brains were submerged into iced isopentane for $25 \mathrm{~s}$ and immediately stored in dry ice and then at $-80^{\circ} \mathrm{C}$ until processing.

\section{Experiment 4: Effects of a Low-Carbohydrate KD on Leptin} Signaling in the Hypothalamus

Twenty-one male, Long Evans rats (Harlan) served as experimental subjects for measurement of phosphorylated STAT3 (pSTAT3) by immunohistochemistry. After 1 week of acclimation to the laboratory, rats were weight-matched and placed on $\mathrm{CH}$ or $\mathrm{KD}$ and allowed to feed ad libitum for 4 weeks. After overnight food deprivation, rats were perfused transcardially for measurement of pSTAT3 following an i.p. injection of leptin $(2 \mathrm{mg} / \mathrm{kg})$ or saline. The $2-\mathrm{mg} / \mathrm{kg}$ dose was selected based on a dose-response 
curve generated to determine the lowest dose at which hypothalamic pSTAT3 was detectable by immunohistochemistry in $\mathrm{CH}$ rats.

To determine the effects of KD on the level of expression of mRNA for SOCS3 and Ob-Rb in the hypothalamus, rats were placed on $\mathrm{CH}(\mathrm{n}=16)$ or $\mathrm{KD}(\mathrm{n}=16)$ for 4 weeks. Rats were then weight-matched within dietary groups. For each dietary group, half was given an i.p. injection of saline and the other half received $2 \mathrm{mg} / \mathrm{kg}$ leptin i.p. On the day of sacrifice, food was removed from the cage $6 \mathrm{~h}$ prior to the onset of the dark cycle, injections were given $4 \mathrm{~h}$ later and rats were sacrificed under ether inhalation anesthesia, followed by rapid decapitation immediately prior to the onset of the dark cycle. Brains were promptly removed and stored in RNAlater (Ambion, Austin, Tex., USA) until processing for gene expression via quantitative real-time PCR.

\section{Plasma Analyses}

Radioimmunoassays (Millipore, St. Charles, Mo., USA) were used to determine levels of plasma leptin. The rat leptin RIA kit had a sensitivity of $0.5 \mathrm{ng} / \mathrm{ml}$. The inter-assay precision was $3.0-$ $5.7 \%$, and the intra-assay precision was $2.0-4.6 \%$. Volumes of 100 $\mu l$ plasma were used in duplicate samples for each assay, as directed by the manufacturer. Plasma triglycerides were measured using a colorimetric, two-enzyme assay (Wako Chemicals USA, Inc., Richmond, Va., USA).

\section{In situ Hybridization}

Brains were coronally sectioned at $14 \mu \mathrm{m}$, mounted onto electrostatically charged Superfrost Plus slides (Fisher Scientific), and stored at $-80^{\circ} \mathrm{C}$. Brain slices were fixed with $4 \%$ paraformaldehyde and dehydrated with an ascending series of alcohols. Sections from each rat containing the arcuate nucleus of the hypothalamus were selected and stored at $-80^{\circ} \mathrm{C}$ for future processing. The POMC plasmid was linearized with the appropriate restriction enzyme and the antisense riboprobe was labelled with ${ }^{35} \mathrm{~S}$ labelled UTP (Perkin Elmer, Boston, Mass., USA), using in vitro transcription systems with $\mathrm{T} 3$ polymerase, according to protocols provided by the manufacturer (Promega Corporation, Madison, Wisc., USA). The probe was then purified using Quick Spin RNA columns (Roche Diagnostics, Indianapolis, Ind., USA).

For processing, slides were warmed and rinsed in triethylamine buffer ( $\mathrm{pH} \mathrm{8.0)} \mathrm{and} \mathrm{triethylamine} \mathrm{with} \mathrm{acetic} \mathrm{anhydride.}$ Sections were incubated in hybridization buffer comprised of $50 \%$ formamide, $0.3 \mathrm{M} \mathrm{NaCl}, 10 \mathrm{~mm}$ Tris $\mathrm{HCl}$ ( $\mathrm{pH} 8.0$ ), $1 \mathrm{nMEDTA}(\mathrm{pH}$ 8.0), $1 \times$ Denhardt's solution (Teknova, Hollister, Calif., USA), $10 \%$ dextran sulfate (Fisher Scientific), $10 \mathrm{mM}$ dithiothreitol (DTT, Sigma, St. Louis, Mo., USA), $500 \mu \mathrm{g} / \mathrm{ml}$ yeast tRNA (Sig$\mathrm{ma})$, and $10^{8} \mathrm{cpm} / \mu \mathrm{l}^{35} \mathrm{~S}$-UTP, and incubated overnight in a $56^{\circ} \mathrm{C}$ humid chamber. After hybridization, sections were washed three times in $2 \times \mathrm{SSC}(3.0 \mathrm{M} \mathrm{NaCl}, 0.3 \mathrm{M}$ sodium citrate; Invitrogen, Carlsbad, Calif., USA) followed by one wash in $2 \times$ SSC + DTT at $56^{\circ} \mathrm{C}$. Slides were then treated with $20 \mu \mathrm{g} / \mathrm{ml}$ RNase A in buffer containing $5 \mathrm{M} \mathrm{NaCl}, 0.5 \mathrm{M}$ EDTA, $1 \mathrm{M}$ Tris, $\mathrm{pH} 7.5$ and $\mathrm{ddH}_{2} \mathrm{O}$. Sections were washed twice in $2 \times$ SSC + DTT, and then twice in $0.1 \times$ SSC + DTT, and dehydrated in an ascending series of alcohols. Slides were exposed to Kodak Biomax film for 2 days. Autoradiographic images were then scanned, and quantified with Scion Image software (National Institutes of Health), utilizing autoradiographic ${ }^{14} \mathrm{C}$-microscales (GE Healthcare, Piscataway, N.J., USA) as a standard. An observer blinded to the treatment of the experimental groups performed scanning and quantification. Data for each animal were means of the product of hybridization area $\times$ density, with the background density subtracted from the three sections, reflecting the region-specific levels of gene expression. Data for each animal were normalized to controls as $100 \%$, and are expressed as mean \pm standard error (SEM).

\section{pSTAT3 Immunohistochemistry}

Ninety minutes after leptin administration, rats were anesthetized with an i.p. injection of sodium pentobarbital and transcardially perfused with ice-cold $0.1 \mathrm{M}$ phosphate-buffered saline (PBS) followed by $4 \%$ paraformaldehyde. Brains were removed, post-fixed in fixative for $4 \mathrm{~h}$ and stored in $20 \%$ sucrose at $4{ }^{\circ} \mathrm{C}$. The following day, brains were frozen and cut into 25 - $\mu \mathrm{m}$-thick freefloating sections. Sections were collected in three series and stored at $4{ }^{\circ} \mathrm{C}$ overnight in $0.1 \mathrm{M}$ PBS containing $0.02 \%$ sodium azide. Sections were rinsed in $1 \% \mathrm{H}_{2} \mathrm{O}_{2}$ and $1 \%$ sodium hydroxide, $0.3 \%$ glycine, and $0.03 \%$ sodium dodecyl sulfate. Blocking was performed in a solution of $0.1 \mathrm{M}$ PBS, $0.025 \%$ Triton, $0.2 \%$ sodium azide, and $3 \%$ normal goat serum for $1 \mathrm{~h}$ at room temperature. Incubation with rabbit polyclonal primary antibody for phosphorylated $\left(\mathrm{Tyr}^{705}\right.$ ) STAT3 (Cell Signaling Technology, Danvers, Mass., USA) was performed at a dilution of 1:1,000 in blocking solution for $24 \mathrm{~h}$ at room temperature. Incubation was continued for another $24 \mathrm{~h}$ at $4^{\circ} \mathrm{C}$. Sections were then washed and incubated with biotinylated anti-rabbit antibody (1:1,000 in blocking solution without sodium azide), followed by avitin-biotin-complex labeling (Vectastain, Vector Labs, Burlingame, Calif., USA). Products of these reactions were visualized with 3,3'-diaminobenzidine. Free-floating sections were then mounted on electrostatically charged microscope slides (VWR, West Chester, Pa., USA) and covered with a $24 \times 60 \mathrm{~mm}$ Slip-Rite glass coverslip (Richard Allan Scientific, Kalamazoo, Mich., USA), which was affixed with DPX tissue mountant.

\section{Cell Counting and Quantification for Immunohistochemistry}

All sections were examined for staining within the acruate nucleus and photographed using SPOT Advanced Software. Stained cell density was determined using ImageJ software (National Institutes of Health, Bethesda, Md., USA). The area of the arcuate nucleus in each section was measured and all stained cells, regardless of staining intensity, within the measured area were counted to determine the density of stained cells in each section. All sections containing the arcuate nucleus were counted for each rat, with the mean density measurement used for analysis.

\section{Quantitative Real-Time PCR}

Hypothalamic blocks were dissected according to the following limits: posterior border of the optic chiasm, anterior border of the mammillary bodies, lateral hypothalamic sulci, and ventral border of the thalamus $[39,41]$. Each hypothalamus was then homogenized in $1 \mathrm{ml}$ of Trizol Reagent (Invitrogen). Following centrifugation of this mixture, RNA was recovered from the aqueous phase by isoproponal precipitation. Any contaminating genomic DNA was then removed by treatment with DNA-free DNase Treatment and Removal Reagents (Applied Biosystems/Ambion), and RNA integrity was determined by agarose gel electrophoresis. cDNA was synthesized from $5 \mu \mathrm{g}$ of RNA using a SuperScript III First-Strand Synthesis System (Invitrogen) for RT-PCR and diluted $1: 3$ in nuclease-free water for storage at $-20^{\circ} \mathrm{C}$. 
Each primer set was optimized such that the correlation coefficient was $0.99-1.0$ and the PCR efficiency was $90-100 \%$. The integrity of the cDNA was confirmed by conventional RT-PCR amplification of L32, a housekeeping gene whose expression serves as a benchmark for comparison to that from the gene of interest [42]. A control reaction for each RNA sample was also performed with no reverse transcriptase enzyme added. Primers for each gene of interest are presented in table 3. Real-time PCR was performed in duplicate using an iCycler and the iQ SYBR Green Supermix (BioRad, Hercules, Calif., USA) with two-step amplification $\left(95^{\circ} \mathrm{C}\right.$ for $10 \mathrm{~s}, 60^{\circ} \mathrm{C}$ for $\left.45 \mathrm{~s}\right)$ for 40 cycles. L32 was amplified from each sample for use as an endogenous control.

\section{Statistics}

In experiments $1 \mathrm{~A}$ and 2 , caloric intake data were analyzed by repeated measures ANOVA followed by Newman-Keuls post hoc comparisons. Data from experiment $1 \mathrm{~B}$ were analyzed by Student's t test. Differences in dietary groups for triglycerides, leptin and fat pad weights were analyzed by individual t tests. The expression of POMC mRNA and number of pSTAT3-positive cells in the arcuate nucleus were analyzed by one-way ANOVA and Tukey's Multiple Comparison Test for post hoc analyses, with the saline-treated $\mathrm{CH}$ group serving as the control.

For quantitative RT-PCR analysis, primers for the genes of interest, Ob-Rb and SOCS-3 as well as the housekeeping ribosomal gene L32 were optimized with a temperature gradient as well as a standard curve using a 1:5 decreasing dilution factor to determine correlation coefficients and reaction efficiencies for each of the primer sets. All primer sets had PCR efficiencies between 98 and $100 \%$ (for a six-dilution standard curve) and correlation coefficients of 0.99 , and were therefore determined to be comparable. Following optimization of the primer sets, the method of Livak and Schmittgen [43] (or the $2^{\wedge}-\Delta \Delta$ CT method) was used to determine relative changes in the genes of interest relative to the housekeeping gene L32. $\Delta$ CTs (i.e. Ob-Rb - L32) were calculated using the mean of duplicates for each sample and were subtracted from the average $\Delta \mathrm{CT}$ for the defined control group. The $\Delta \Delta \mathrm{CT}$ s were then used to calculate a fold change relative to the control group. $\mathrm{CH}$ values were compared to KD values by a Student's t test. A value of $\mathrm{p}<0.05$ was considered significant, and all data are represented as a mean \pm standard error of the mean (SEM).

\section{Results}

Experiment 1: Responsivity to the Anorectic Effects of Peripherally Administered Leptin

As depicted in figure 1a, analysis of caloric intake $24 \mathrm{~h}$ after injection revealed that in $\mathrm{CH}$ rats, a dose of $2 \mathrm{mg} / \mathrm{kg}$ was required to significantly reduce intake as compared to 24-hour intake following i.p. saline injection $(\mathrm{p}<0.05)$. In contrast, caloric intake was reduced in KD rats $24 \mathrm{~h}$ after both doses of leptin (100 and $200 \mu \mathrm{g})$ as compared to intake following i.p. saline $(\mathrm{p}<0.05$ in both cases).
Table 1. Composition of the low-carbohydrate, high-fat KD (D06040601, Research Diets Inc., New Brunswick, N.J., USA)

\begin{tabular}{lrr}
\hline & $\mathrm{g}$ & $\mathrm{kcal}$ \\
\hline Protein & & \\
$\quad$ Casein, 80 mesh & 151 & 604 \\
$\quad$ L-Cysteine & 1.5 & 6 \\
Carbohydrate & & \\
$\quad$ Corn starch & 40 & 160 \\
$\quad$ Cellulose, BW200 & 50 & 0 \\
Fat & 25 & 225 \\
$\quad$ Soybean oil & 336 & 3,024 \\
$\quad$ Lard & 10 & 40 \\
Vitamin mix, V10001 & 0.025 & 0 \\
FD\&C Yellow Dye No. 5 & 0.025 & 0 \\
FD\&C Blue Dye No. 1 & 660.55 & 4,059 \\
\hline Total & & \\
\hline
\end{tabular}

Table 2. Effects of diet type on adiposity, $\beta$-hydroxybutyrate, plasma leptin and triglyceride levels

\begin{tabular}{lcc}
\hline & $\mathrm{CH}$ & $\mathrm{KD}$ \\
\hline $\begin{array}{l}\text { Body weight change from } \\
\quad \text { start of experiment, g }\end{array}$ & $99.2 \pm 5.4$ & $105.7 \pm 11.7$ \\
Epididymal fat, g & $2.81 \pm 0.35$ & $5.14 \pm 0.89^{*}$ \\
Retroperitoneal fat, g & $2.61 \pm 0.42$ & $4.68 \pm 0.56^{*}$ \\
Subcutaneous fat, g & $3.65 \pm 0.38$ & $3.97 \pm 0.42$ \\
$\beta$-Hydroxybutyrate, mmol/l & $0.21 \pm 0.02$ & $0.33 \pm 0.03^{*}$ \\
Leptin, ng/ml & $2.99 \pm 0.26$ & $8.65 \pm 1.99^{*}$ \\
Triglyceride, mg/dl & $94.02 \pm 15.95$ & $100.52 \pm 14.0$ \\
\hline
\end{tabular}

${ }^{*} \mathrm{p}<0.05$ : significant difference between $\mathrm{CH}$ and $\mathrm{KD}$ groups.

\section{Experiment 2: Responsivity to the Anorectic Effects of Centrally Administered Leptin in Rats Maintained on a KD}

There were no differences in responsivity to the anorectic effects of i.c.v. leptin between the dietary groups. Rats in both dietary groups significantly reduced caloric intake $24 \mathrm{~h}$ after i.c.v. injection of $15 \mu \mathrm{g}$ leptin as compared to intake following i.c.v. saline. $\mathrm{CH}$ and $\mathrm{KD}$ intake were similarly reduced after $15 \mu \mathrm{g}$ leptin i.c.v. $(\mathrm{p}<0.05$ for both diet groups; fig. 2a, b).

As described in table 2, there were no diet-related differences in change in body weight. Epididymal and retroperitoneal fat gain was significantly greater in $\mathrm{KD}$ rats $(\mathrm{p}<0.05$ in both cases). Maintenance on a KD did indeed result in significantly elevated $\beta$-hydroxybutyrate levels 

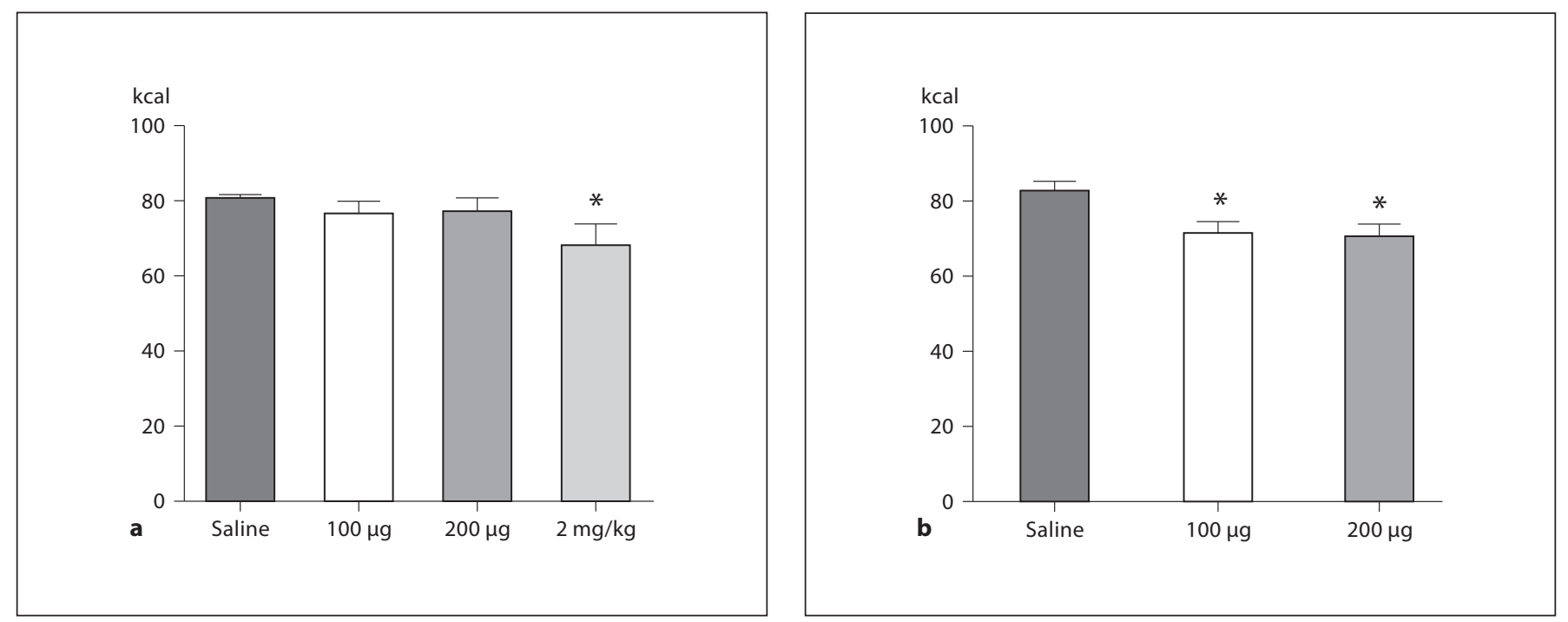

Fig. 1. Caloric intake after i.p. leptin. Rats maintained on $\mathrm{CH}(\mathbf{a})$ or $\mathrm{KD}(\mathbf{b})$ were injected i.p. with saline or leptin and caloric intake was measured $24 \mathrm{~h}$ later. For $\mathrm{CH}$ rats, a dose of $2 \mathrm{mg} / \mathrm{kg}$ was required to significantly reduce caloric intake at $24 \mathrm{~h}$. In contrast, KD rats reduced caloric intake in response to both 100 and $200 \mu \mathrm{g}$ leptin. ${ }^{*} \mathrm{p}<0.05$ when intake was compared to intake following saline administration.

Table 3. Primer sequences for each gene are presented with the annealing temperature

\begin{tabular}{|c|c|c|}
\hline Gene & Primer sequences & Temperature, ${ }^{\circ} \mathrm{C}$ \\
\hline L32 & $\begin{array}{l}\text { Forward: 5'-CAG ACG CAC CAT CGA AGT TA-3' } \\
\text { Reverse: 5'-AGC CAC AAA GGA CGT GTT TC-3' }\end{array}$ & 60 \\
\hline SOCS3 & $\begin{array}{l}\text { Forward: } 5^{\prime} \text {-TTC TTT ACC ACC GAC GGA AC-3' } \\
\text { Reverse: } 5^{\prime} \text {-TTT CCC ACA TCT TGT GAC CA-3' }\end{array}$ & 60 \\
\hline $\mathrm{Ob}-\mathrm{Rb}$ & Forward: 5' -TTC TTT ACC ACC GAC GGA AC-3' & 60 \\
\hline
\end{tabular}

in $\mathrm{KD}$ rats $(\mathrm{p}<0.05)$, and while leptin levels were significantly increased in $\mathrm{KD}$ as compared to $\mathrm{CH}(\mathrm{p}<0.05)$, plasma triglyceride levels were significantly reduced in KD rats $(\mathrm{p}<0.05)$.

\section{Experiment 3: Effect of Peripheral or Central Leptin}

Administration on Arcuate POMC mRNA Expression in Rats Maintained on a Low-Carbohydrate KD

Administration of i.p. leptin increased POMC mRNA in $\mathrm{CH}$-fed rats following the $2-\mathrm{mg} / \mathrm{kg}$ dose by $55.8 \%$ as compared to expression levels following i.p. saline ( $\mathrm{p}<$ 0.05 ; fig. 3a), but was unaffected by $100 \mu \mathrm{g}$ leptin. This is in contrast to the effects of i.p. leptin in KD rats. As ex- pected from our previous research [38], POMC mRNA expression was significantly lower in KD rats after saline injection (59.75\% of control level). After $100 \mu \mathrm{g}$ leptin, POMC mRNA expression was increased to $207.6 \%$ of the level of expression in controls $(\mathrm{p}<0.05)$.

Following i.c.v. leptin injection, $\mathrm{CH}$ rats had significantly increased POMC mRNA in the arcuate after $15 \mu \mathrm{g}$ leptin as compared to $\mathrm{CH}$ controls $(\mathrm{p}<0.05)$. As depicted in figure $3 \mathrm{~b}, 5 \mu \mathrm{g}$ leptin did not affect POMC mRNA expression levels in $\mathrm{CH}$ rats. As previously described [38], rats maintained on a $\mathrm{KD}$ had a significantly lower level of POMC mRNA expression than $\mathrm{CH}$ rats at baseline ( $\mathrm{p}<$ 0.05 ; fig. 2b). Following administration of $5 \mu \mathrm{g}$ leptin, 

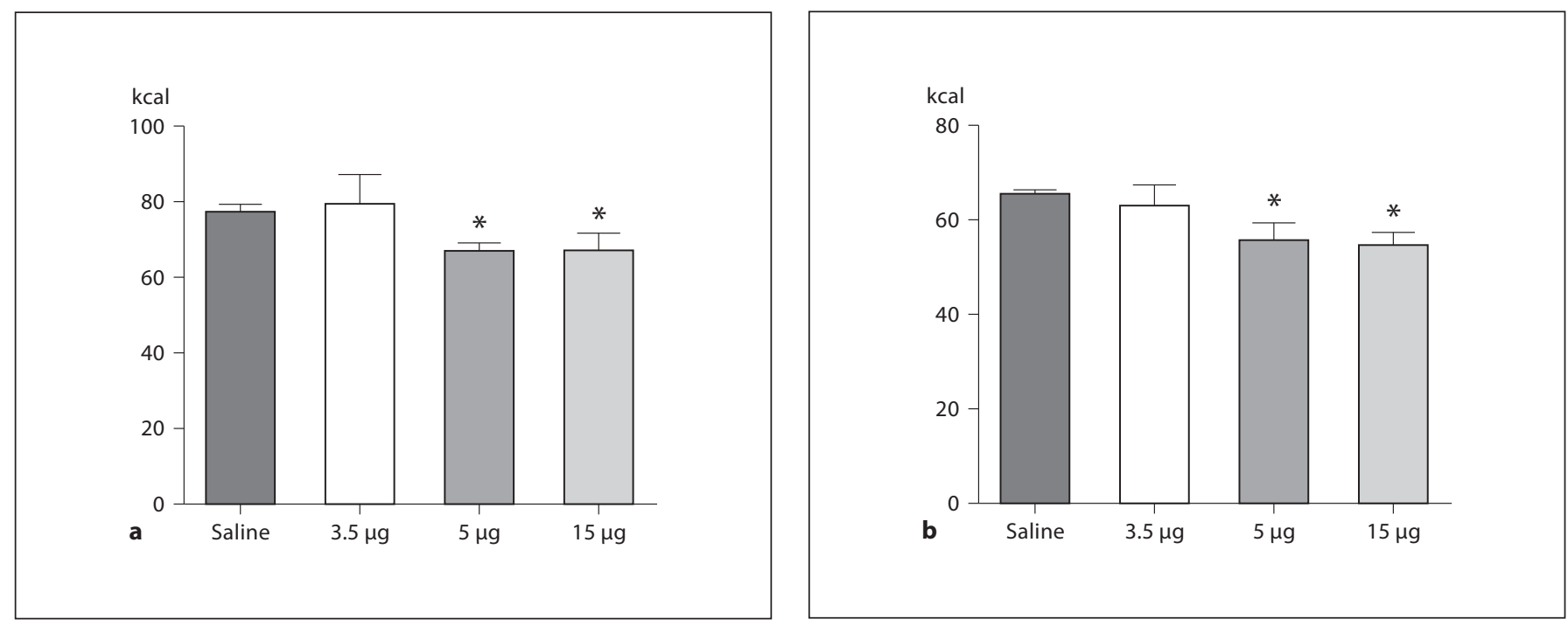

Fig. 2. Caloric intake after i.c.v. leptin. Rats maintained on $\mathrm{CH}(\mathbf{a})$ or $\mathrm{KD}(\mathbf{b})$ were injected into the lateral ventricle with saline or leptin. Caloric intake was measured $24 \mathrm{~h}$ after injection. For both dietary groups, caloric intake was significantly decreased $24 \mathrm{~h}$ after i.c.v. administration of $15 \mu \mathrm{g}$ leptin. ${ }^{*} \mathrm{p}<0.05$ when intake was compared to intake following saline administration.
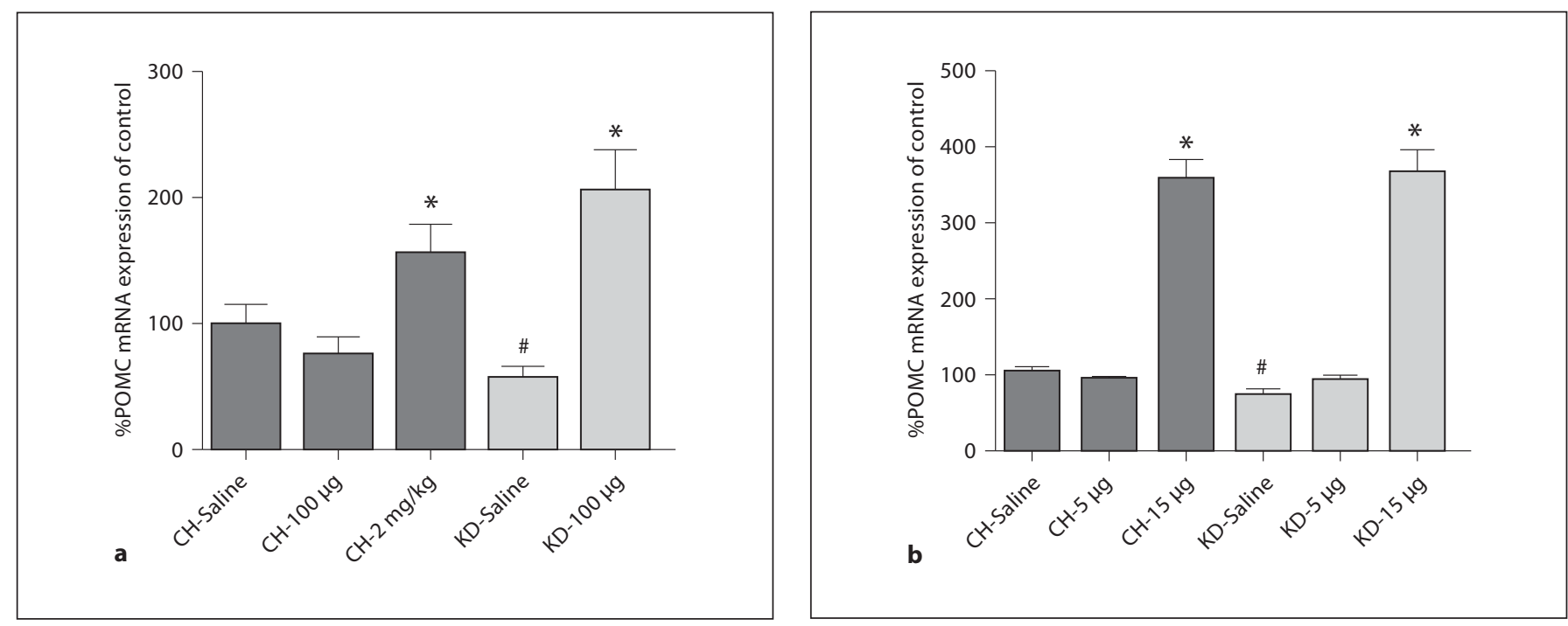

Fig. 3. Hypothalamic neuropeptide mRNA expression following i.p. or i.c.v. leptin. POMC mRNA expression levels in the arcuate nucleus were assessed by in situ hybridization following i.p. (a) or administration of leptin in $\mathrm{CH}$ and $\mathrm{KD}$ rats (b). At baseline, POMC mRNA was significantly lower in KD rats. Following i.p. administration of leptin, POMC was increased in rats under both dietary conditions. i.c.v. administration of $5 \mu \mathrm{g}$ leptin was sufficient to normalize POMC mRNA expression levels in KD rats to those of $\mathrm{CH}$ controls, and both dietary groups significantly increased POMC mRNA in response to $15 \mu \mathrm{g}$ leptin. Data are means \pm SEM and different symbols ( ${ }^{*}$ and \#) denote significant differences between treatment responses $(\mathrm{p}<0.05)$ as compared to expression levels in $\mathrm{CH}$ rats after saline treatment. 

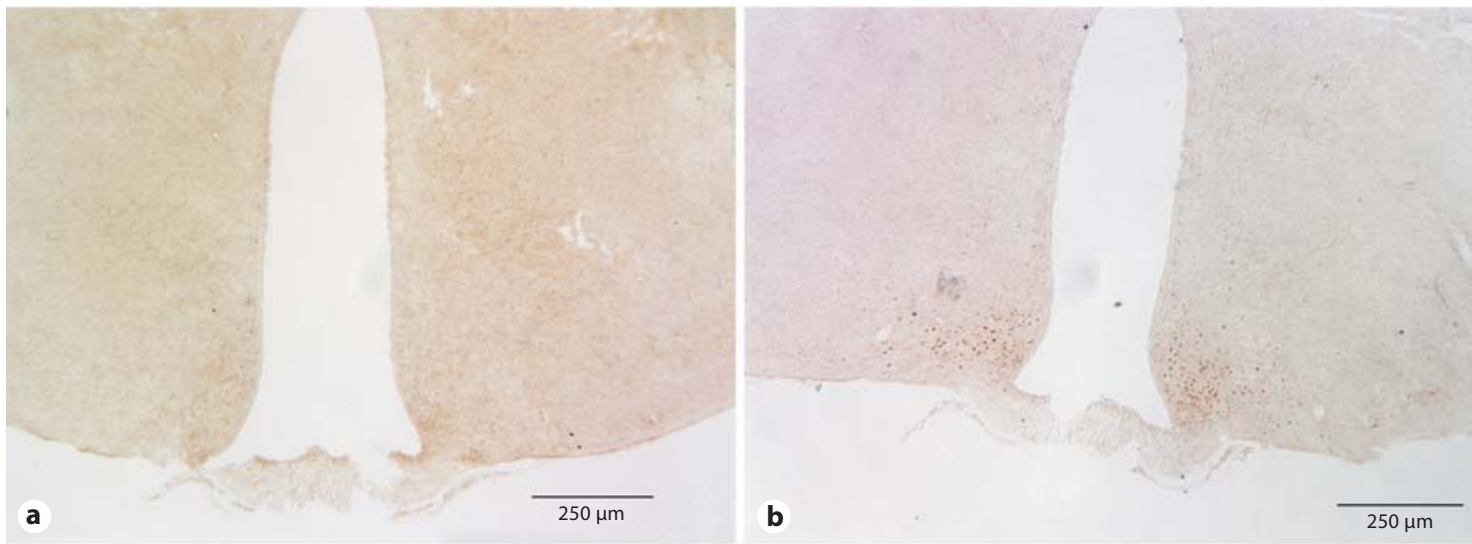

KD-Saline

\section{KD-Leptin}
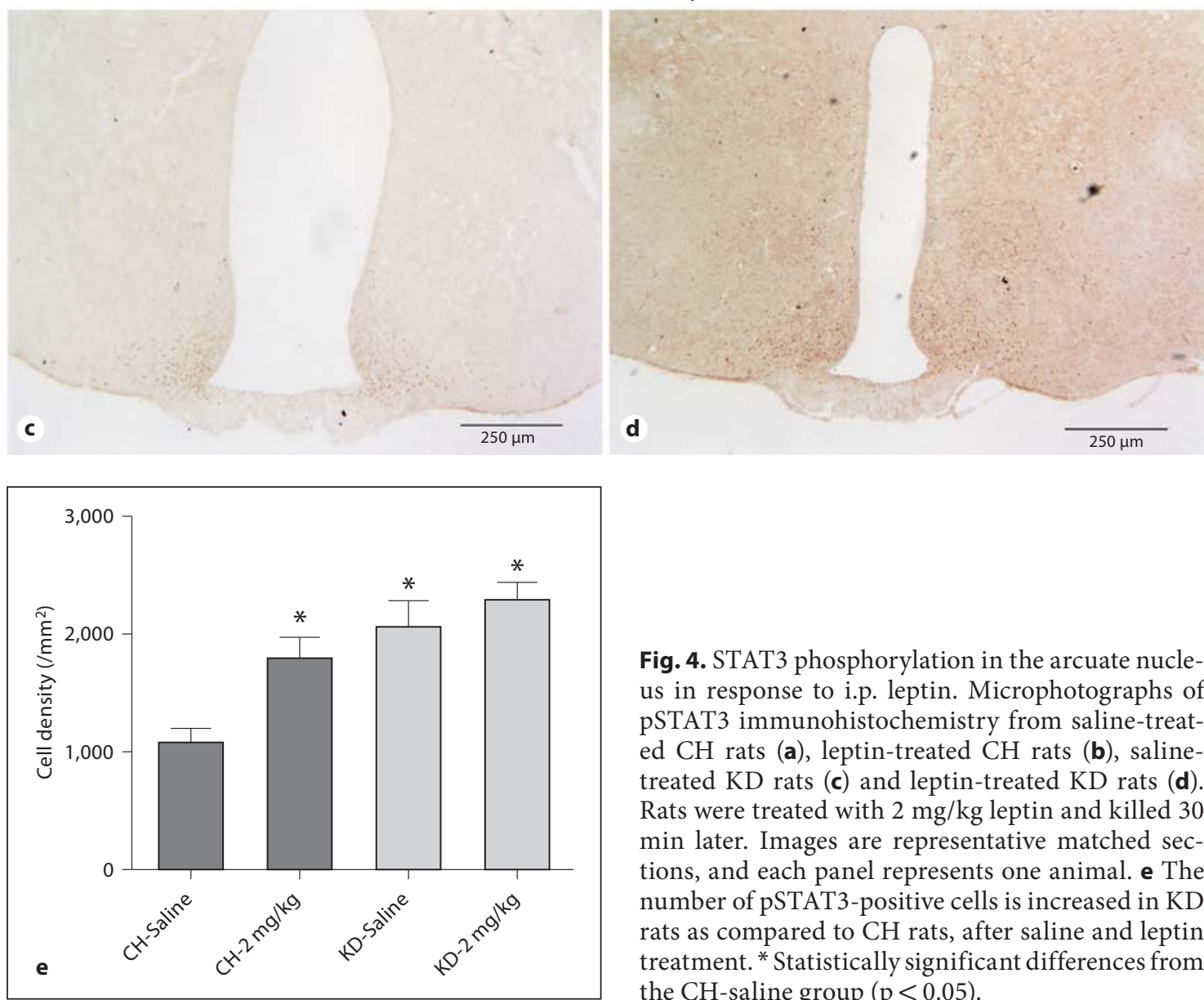

Fig. 4. STAT3 phosphorylation in the arcuate nucleus in response to i.p. leptin. Microphotographs of pSTAT3 immunohistochemistry from saline-treated $\mathrm{CH}$ rats (a), leptin-treated $\mathrm{CH}$ rats (b), salinetreated $\mathrm{KD}$ rats $(\mathbf{c})$ and leptin-treated $\mathrm{KD}$ rats $(\mathbf{d})$. Rats were treated with $2 \mathrm{mg} / \mathrm{kg}$ leptin and killed 30 min later. Images are representative matched sections, and each panel represents one animal. e The number of pSTAT3-positive cells is increased in KD rats as compared to $\mathrm{CH}$ rats, after saline and leptin treatment. ${ }^{*}$ Statistically significant differences from the $\mathrm{CH}$-saline group $(\mathrm{p}<0.05)$.

POMC mRNA expression was normalized to that of $\mathrm{CH}$ controls and significantly higher than in saline-treated $\mathrm{KD}$ rats $(\mathrm{p}<0.05)$. POMC mRNA expression was increased to $255 \%$ of $\mathrm{CH}$ control values following $15 \mu \mathrm{g}$ leptin $(\mathrm{p}<0.05)$.

Leptin Sensitivity and the Ketogenic Diet
Experiment 4: Effects of a Low-Carbohydrate KD on Leptin Signaling in the Hypothalamus

Maintenance on a KD resulted in significant differences in pSTAT3 levels (fig. 4). In $\mathrm{CH}$ rats, leptin treatment induced significantly more STAT3 phosphorylation 


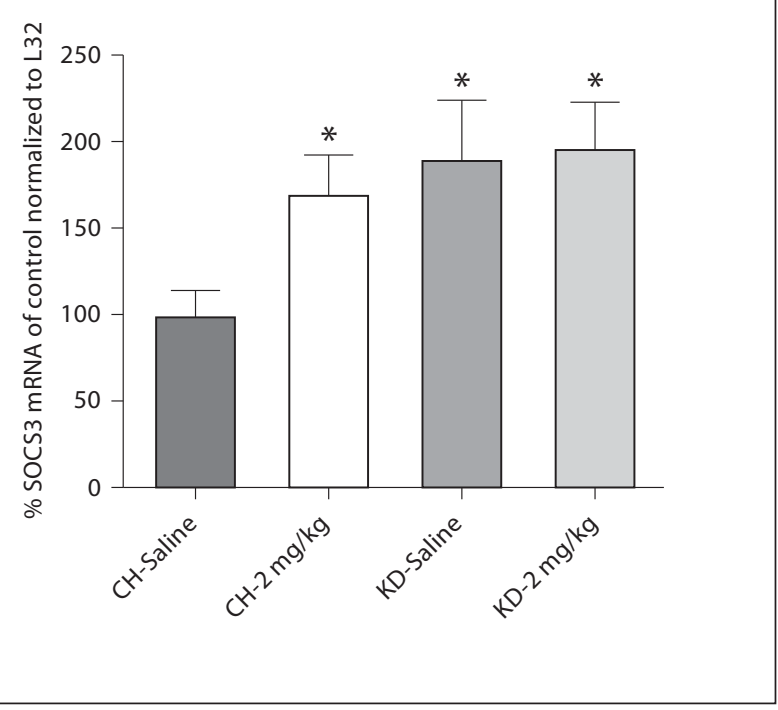

Fig. 5. Hypothalamic SOCS3 mRNA. Following 4 weeks of maintenance on $\mathrm{CH}$ or $\mathrm{KD}$, SOCS3 mRNA was significantly increased in $\mathrm{KD}$ rats as compared to $\mathrm{CH}$ rats. SOCS3 mRNA expression was increased in $\mathrm{CH}$ rats after leptin treatment, but did not change from baseline in KD rats. * Statistically significant differences from the $\mathrm{CH}$-saline group ( $\mathrm{p}<0.05)$.

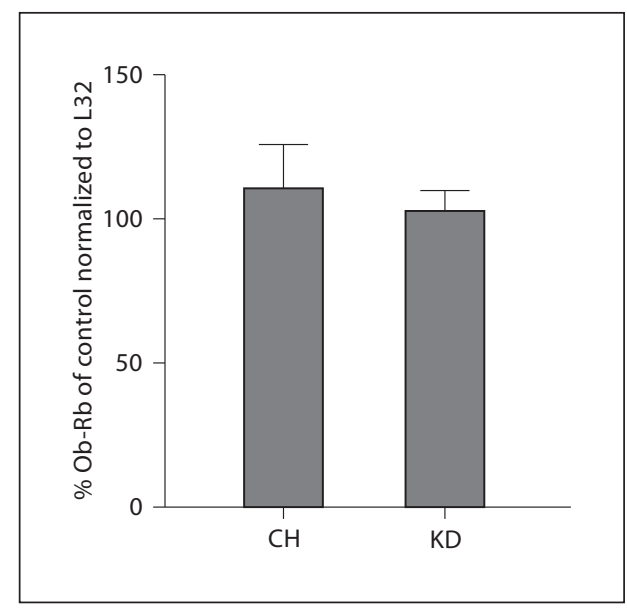

Fig. 6. Hypothalamic Ob-Rb mRNA. Following 4 weeks of maintenance on $\mathrm{CH}$ or $\mathrm{KD}$, there were no differences in hypothalamic $\mathrm{Ob}-\mathrm{Rb}$ expression between the dietary groups.

in the arcuate nucleus as compared to $\mathrm{CH}$ rats that were treated with saline (fig. $4 \mathrm{a}$ vs. b, $\mathrm{p}<0.05$; fig. 4 e). The level of pSTAT3 in KD rats after saline treatment was significantly greater than that in saline-treated $\mathrm{CH}$ rats (fig. 4 a vs. c, p $<0.05$; fig. 4 e). Whereas leptin treatment increased the number of pSTAT3-positive cells in $\mathrm{CH}$ rats, it was ineffective at increasing pSTAT3 in KD rats as compared to pSTAT3 in saline-treated KD rats (fig. 4c vs. d).

Similar to the effects of a KD on pSTAT3, rats maintained on a KD had significantly increased expression of SOCS3 mRNA in the hypothalamus as compared to $\mathrm{CH}$ fed controls. Following saline treatment, SOCS3 mRNA expression was $93.2 \%$ greater in $\mathrm{KD}$ rats than in $\mathrm{CH}$ rats (fig. 5). Leptin administration $(2 \mathrm{mg} / \mathrm{kg})$ increased SOCS3 mRNA expression in $\mathrm{CH}$ rats $(71.6 \%)$ as compared to the expression level after saline administration. In KD rats, leptin administration did not increase SOCS3 mRNA expression as compared to the level of expression in $\mathrm{KD}$ rats after saline treatment. Finally, analysis of expression levels of $\mathrm{Ob}-\mathrm{Rb}$ in the hypothalamus demonstrated that there was no effect of diet on this parameter (fig. 6).

\section{Discussion}

The KD is high in fat content, as are many diets used to investigate diet-induced obesity. It differs from traditional high-fat diets, however, in that the carbohydrate content is severely reduced and consumption of this diet results in the production of ketone bodies. The purpose of our current experiments was to evaluate how maintenance on a KD may affect sensitivity to the anorectic effects of leptin, as the effects of ketone bodies on factors involved in the neuroendocrine regulation of energy balance have not been elucidated.

We have previously reported that rats maintained on a KD consume the same amount of calories and gain the same amount of overall body weight as do $\mathrm{CH}$ controls, but have increased adiposity and plasma leptin levels, and decreased POMC $\mathrm{mRNA}$ expression in the arcuate nucleus [38]. Importantly, while $\mathrm{KD}$ rats weigh the same as $\mathrm{CH}$ rats, the increases in plasma leptin and adiposity are significantly greater than in rats maintained on a high-fat non-KD [38]. Because leptin resistance has been well documented in rats maintained on high-fat non-KDs that induce increased adiposity and concomitant high-leptin levels $[5,25,31,44]$, and KD rats have increased plasma leptin levels, reduced POMC mRNA in the arcuate nucleus, and do not decrease caloric intake as compared to $\mathrm{CH}$ controls, we hypothesized that KD rats may have a loss of sensitivity to the anorectic effects of leptin. Our present experiments, however, demonstrate the opposite. A lower dose of leptin was required to reduce the caloric intake of $\mathrm{KD}$ rats than was required to do so in $\mathrm{CH}$ rats when leptin 
was delivered peripherally, demonstrating a lack of resistance to peripheral leptin in $\mathrm{KD}$ rats. In the brain, the same dose that reduced caloric intake in $\mathrm{CH}$ rats reduced caloric intake in $\mathrm{KD}$ rats, demonstrating a lack of central leptin resistance.

Given that KD rats remained responsive to the anorectic effects of peripheral and central leptin administration, we sought to determine the effects of KD exposure on components of the hypothalamic signaling system that mediates leptin's actions. We have previously demonstrated the effects of a KD on the central melanocortin system, including decreased basal POMC mRNA expression in the arcuate, increased responsivity to agonism of MC3/4R, and increased expression levels of MC4R mRNA in the paraventricular nucleus of the hypothalamus [38]. Here we report that POMC neurons in the arcuate nucleus of the hypothalamus were responsive to administration of peripheral and central leptin in $\mathrm{KD}$ rats. Whereas $\mathrm{CH}$ rats required $2 \mathrm{mg} / \mathrm{kg}$ i.p. in order to elicit an increase in POMC mRNA expression levels in the arcuate, POMC was increased in KD rats with $100 \mu \mathrm{g}$ i.p. leptin. These results differ from the effects of leptin on POMC mRNA expression in DIO mice. Previous research has demonstrated that i.p. leptin administered to DIO mice was unable to stimulated POMC mRNA expression above baseline levels [36]. Interestingly, in our current experiments we report that i.c.v. leptin administration to KD rats at a dose that was ineffective at reducing caloric intake in either dietary group normalized POMC expression to that of saline-treated $\mathrm{CH}$ rats, and significantly increased POMC as compared to salinetreated $\mathrm{KD}$ rats. A similar increase in POMC was observed in $\mathrm{CH}$ and $\mathrm{KD}$ rats after central administration of leptin at the dose required to reduce caloric intake. Collectively, these data demonstrate that while endogenous leptin in KD rats is insufficient to increase POMC mRNA, POMC neurons are highly sensitive to exogenous leptin stimulation.

While intact POMC responsivity to exogenous leptin administration provides one mechanism by which leptin may retain its ability to reduce caloric intake in $\mathrm{KD}$ rats, the effect of a KD on the level of phosphorylation of STAT-3 in the arcuate nucleus and of SOCS3 in the hypothalamus complicates interpretations. Evaluation of the pSTAT3 in the arcuate nucleus revealed that KD rats had basal levels of pSTAT3 that were indistinguishable from those elicited by leptin stimulation in $\mathrm{CH}$ rats. Additionally, the number of pSTAT3-positive cells was not increased in $\mathrm{KD}$ rats as compared to those after saline treatment in $\mathrm{KD}$, as it was in $\mathrm{CH}$ rats. While the lack of leptin-

Leptin Sensitivity and the Ketogenic Diet stimulated pSTAT3 increase in KD rats is consistent with the effects of maintenance on a high-fat diet [24], the basal increase suggests that maintenance on a KD may result in a chronically increased level of phosphorylation of STAT3, rendering the system constitutively more active than in rodents maintained on other types of diets.

Similar to the effects of a KD on pSTAT3, KD rats had higher basal levels of SOCS3 mRNA expression in the hypothalamus as compared to $\mathrm{CH}$ controls. Whereas SOCS3 mRNA expression increased in $\mathrm{CH}$-fed animals after leptin administration, it remained the same in KD rats following leptin administration. Because increased SOCS3 has been demonstrated in DIO, leptin-resistant rodents $[24,35]$, it would follow that increased SOCS3 in KD rats would be associated with leptin resistance. Additionally, in $\mathrm{CH}$-fed rodents, STAT3 has been demonstrated to activate not only SOCS3 but also transcription of POMC [22]. While the STAT3-SOCS3 relationship is intact in KD rats, the lack of increased POMC in the basal state suggests a disconnection of the relationship between STAT3 and POMC that requires further investigation. Importantly, there are multiple signaling pathways by which leptin exerts its actions, including autophosphorylation of Jak 2 and activation of the IRS/phosphatidylinositol-3'-kinase pathway [for review, see 45]. The effects of a KD on these signaling pathways have not yet been elucidated, and may provide evidence for the mechanisms by which KD maintenance results in the preservation of the ability to respond to exogenous leptin administration.

Responsivity to the anorectic effects of exogenous leptin in KD rats, despite levels of pSTAT3 and SOCS3 that would suggest leptin resistance, is potentially due to multiple factors attributable to the unique neuroendocrine profile induced by maintenance on this diet. For example, there is generally a positive correlation between leptin and insulin; however maintenance on a KD results in increased plasma leptin with decreased plasma insulin levels. Thus, the KD induces a state in which the brain receives signals of abundant energy stores in the form of increased leptin, yet also receives information signaling lack of energy stores in the form of low insulin, in addition to the presence of ketone bodies. The consequences of disconnecting these two adiposity signals are currently unknown, and likely play a role in mediating overall effects of a KD on energy balance. Additionally, whether the effects of a KD on the leptin system as reported here are an early adaptation to the diet or persist over time and the role of hindbrain leptin signaling with regard to KD maintenance are unknown and require further investigation.

Neuroendocrinology 2010;92:100-111 109 
In addition, the level of plasma triglycerides affects responsivity to peripheral leptin. Banks et al. [46] have demonstrated that triglycerides inhibit transport of leptin across the $\mathrm{BBB}$, mediating resistance to peripherally circulating leptin. Triglycerides regulate the rate at which leptin is transported across the BBB in an inverse relationship such that greater levels of serum triglycerides result in a decreased rate of leptin transport [46]. Despite the high level of dietary fat in $\mathrm{KD}$, plasma triglyceride levels are not elevated in association with KD consumption as compared to $\mathrm{CH}$ rats. Diet-related differences in triglyceride levels may, regardless of elevated adiposity, help preserve the ability of the leptin transport system across the BBB that is impaired when adiposity and triglyceride levels are increased. Although speculative at this juncture, it is possible that $\mathrm{KD}$ effects on triglycerides may prevent the triglyceride-associated decrease in the rate of leptin transport across the BBB.

In our studies, maintenance on a KD (5\% carbohydrate, $80 \%$ fat, and $15 \%$ protein) induces a unique metabolic state in which plasma leptin levels are elevated, whereas insulin levels are suppressed. This effect appears to be dependent on diet type and species, as other lowcarbohydrate diets do not produce the profound increases in leptin and adiposity, and mice and humans have been demonstrated to lose weight on KDs [47-50]. In rats, Morens et al. [51] implemented a low-carbohydrate diet from which $5.1 \%$ of the calories were derived from carbohydrate sources, $60.2 \%$ from fat, and $34.7 \%$ from protein. Maintenance on this diet resulted in body weights that were indistinguishable from those of rats maintained on $\mathrm{CH}$, as is the case with the KD used in our present stud- ies; however plasma leptin was not elevated despite increased adiposity [51]. It is likely that variations in levels of dietary protein contributed to differential findings. The influence of dietary macronutrient distribution on body weight is further demonstrated by studies in which rats were placed on a low-carbohydrate diet composed of $1.3 \%$ carbohydrate, $94 \%$ fat, and $4.2 \%$ protein. Under these conditions, rats lost weight yet gained more adipose mass than $\mathrm{CH}$-fed counterparts [52]. The data are further complicated by studies in mice. Mice maintained on a KD (86\% fat and $13.3 \%$ protein) transiently lost weight and maintained a lower body weight than $\mathrm{CH}$-fed controls. This diet, in mice, resulted in decreased plasma insulin, and no differences in adiposity or plasma leptin [47]. Given these differential findings, consideration of dietary macronutrient content is an important factor in discerning diet effects on endocrine and behavioral parameters.

In conclusion, our current findings demonstrate that maintenance on a KD, which results in increased adiposity and leptin in the rat, does not induce resistance to exogenously administered leptin. This is despite the presence of markers of leptin resistance, including increased basal SOCS3 mRNA that is measured in DIO rodents that are leptin-resistant $[24,25,45,53]$ and the absence of leptin-stimulated increases in pSTAT3 and SOCS3. While there are notable differences in the manner by which rats and humans respond to a $\mathrm{KD}$, elucidation of the neural and endocrine effects of decreased carbohydrate and chronically elevated ketone bodies provides insight into how dietary macronutrients affect individual systems involved in overall regulation of energy balance.

\section{References}

$\checkmark 1$ Maffei M, Halaas J, Ravussin E, et al: Leptin levels in human and rodent: measurement of plasma leptin and ob RNA in obese and weight-reduced subjects. Nat Med 1995;1: 1155-1161.

-2 Considine RV, Sinha MK, Heiman ML, et al: Serum immunoreactive-leptin concentrations in normal-weight and obese humans. N Engl J Med 1996;334:292-295.

$\checkmark 3$ Frederich RC, Hamann A, Anderson S, et al: Leptin levels reflect body lipid content in mice: evidence for diet-induced resistance to leptin action. Nat Med 1995;1:1311-1314.

$\checkmark 4$ Campfield LA, Smith FJ, Guisez Y, et al: Recombinant mouse OB protein: evidence for a peripheral signal linking adiposity and central neural networks. Science 1995;269:546549.
5 Halaas JL, Boozer C, Blair-West J, et al: Physiological response to long-term peripheral and central leptin infusion in lean and obese mice. Proc Natl Acad Sci USA 1997;94:88788883.

6 Pelleymounter MA, Cullen MJ, Baker MB, et al: Effects of the obese gene product on body weight regulation in ob/ob mice. Science 1995;269:540-543.

7 Elmquist JK, Elias CF, Saper CB: From lesions to leptin: hypothalamic control of food intake and body weight. Neuron 1999;22: 221-232.

$>8$ Schwartz MW, Woods SC, Porte D Jr, et al: Central nervous system control of food intake. Nature 2000;404:661-671.
9 Banks WA, Kastin AJ, Huang W, et al: Leptin enters the brain by a saturable system independent of insulin. Peptides 1996;17:305311.

10 Tartaglia LA: The leptin receptor. J Biol Chem 1997;272:6093-6096.

11 Kloek C, Haq AK, Dunn SL, et al: Regulation of Jak kinases by intracellular leptin receptor sequences. J Biol Chem 2002;277:4154741555.

12 Chua SC Jr, Chung WK, Wu-Peng XS, et al: Phenotypes of mouse diabetes and rat fatty due to mutations in the $\mathrm{OB}$ (leptin) receptor. Science 1996;271:994-996.

13 Lee GH, Proenca R, Montez JM, et al: Abnormal splicing of the leptin receptor in diabetic mice. Nature 1996;379:632-635. 
-14 Ur E, Wilkinson DA, Morash BA, Wilkinson M: Leptin immunoreactivity is localized to neurons in rat brain. Neuroendocrinology 2002;75:264-272.

15 Cheung CC, Clifton DK, Steiner RA: Proopiomelanocortin neurons are direct targets for leptin in the hypothalamus. Endocrinology 1997; 138:4489-4492.

-16 Korner J, Chua SC Jr, Williams JA, et al: Regulation of hypothalamic proopiomelanocortin by leptin in lean and obese rats. Neuroendocrinology 1999;70:377-383.

$\checkmark 17$ Mercer JG, Moar KM, Rayner DV, et al: Regulation of leptin receptor and NPY gene expression in hypothalamus of leptin-treated obese (ob/ob) and cold-exposed lean mice. FEBS Lett 1997;402:185-188.

- 18 Schwartz MW, Baskin DG, Bukowski TR, et al: Specificity of leptin action on elevated blood glucose levels and hypothalamic neuropeptide $\mathrm{Y}$ gene expression in ob/ob mice. Diabetes 1996;45:531-535.

-19 Schwartz MW, Seeley RJ, Woods SC, et al: Leptin increases hypothalamic pro-opiomelanocortin mRNA expression in the rostral arcuate nucleus. Diabetes 1997;46:21192123.

20 Elias CF, Aschkenasi C, Lee C, et al: Leptin differentially regulates NPY and POMC neurons projecting to the lateral hypothalamic area. Neuron 1999;23:775-786.

21 Banks AS, Davis SM, Bates SH, Myers MG Jr: Activation of downstream signals by the long form of the leptin receptor. J Biol Chem 2000; 275:14563-14572.

22 Munzberg H, Huo L, Nillni EA, et al: Role of signal transducer and activator of transcription 3 in regulation of hypothalamic proopiomelanocortin gene expression by leptin. Endocrinology 2003;144:2121-2131.

-23 Van Heek M, Compton DS, France CF, et al: Diet-induced obese mice develop peripheral, but not central, resistance to leptin. J Clin Invest 1997;99:385-390.

24 Munzberg H, Flier JS, Bjorbaek C: Regionspecific leptin resistance within the hypothalamus of diet-induced obese mice. Endocrinology 2004; 145:4880-4889.

25 Widdowson PS, Upton R, Buckingham R, et al: Inhibition of food response to intracerebroventricular injection of leptin is attenuated in rats with diet-induced obesity. Diabetes 1997;46:1782-1785.

26 Fam BC, Morris MJ, Hansen MJ, et al: Modulation of central leptin sensitivity and energy balance in a rat model of diet-induced obesity. Diabetes Obes Metab 2007;9:840852.
27 Banks WA, Farrell CL: Impaired transport of leptin across the blood-brain barrier in obesity is acquired and reversible. Am J Physiol Endocrinol Metab 2003;285:E10-E15.

28 Caro JF, Kolaczynski JW, Nyce MR, et al: Decreased cerebrospinal-fluid/serum leptin ratio in obesity: a possible mechanism for leptin resistance. Lancet 1996;348:159-161.

29 Prpic V, Watson PM, Frampton IC, et al: Differential mechanisms and development of leptin resistance in $\mathrm{A} / \mathrm{J}$ versus $\mathrm{C} 57 \mathrm{BL} / 6 \mathrm{~J}$ mice during diet-induced obesity. Endocrinology 2003;144:1155-1163.

30 Myers MG Jr: Leptin receptor signaling and the regulation of mammalian physiology. Recent Prog Horm Res 2004;59:287-304.

-31 Levin BE, Dunn-Meynell AA: Reduced central leptin sensitivity in rats with diet-induced obesity. Am J Physiol Regul Integr Comp Physiol 2002;283:R941-R948.

- 32 El-Haschimi K, Pierroz DD, Hileman SM, et al: Two defects contribute to hypothalamic leptin resistance in mice with diet-induced obesity. J Clin Invest 2000;105:1827-1832.

33 Sahu A: Effects of chronic central leptin infusion on proopiomelanocortin and neurotensin gene expression in the rat hypothalamus. Neurosci Lett 2008;440:125-129.

$34 \mathrm{Pal}$ R, Sahu A: Leptin signaling in the hypothalamus during chronic central leptin infusion. Endocrinology 2003;144:3789-3798.

35 Bjorbaek C, Elmquist JK, Frantz JD, et al: Identification of SOCS-3 as a potential mediator of central leptin resistance. Mol Cell 1998;1:619-625.

36 Enriori PJ, Evans AE, Sinnayah P, et al: Dietinduced obesity causes severe but reversible leptin resistance in arcuate melanocortin neurons. Cell Metab 2007;5:181-194.

37 Mori H, Hanada R, Hanada T, et al: Socs3 deficiency in the brain elevates leptin sensitivity and confers resistance to diet-induced obesity. Nat Med 2004;10:739-743.

- 38 Kinzig KP, Scott KA, Hyun J, et al: Altered hypothalamic signaling and responses to food deprivation in rats fed a low-carbohydrate diet. Obes Res 2005;13:1672-1682.

39 Paxinos G, Watson C: The Rat Brain in Stereotaxic Coordinates, ed 2. New York, Academic Press, 1986.

40 Rich AJ: Ketone bodies as substrates. Proc Nutr Soc 1990;49:361-373.
41 Cambronero JC, Rivas FJ, Borrell J, Guaza C: Interleukin-1-beta induces pituitary adrenocorticotropin secretion: evidence for glucocorticoid modulation. Neuroendocrinology 1992;55:648-654.

42 Thellin O, Zorzi W, Lakaye B, et al: Housekeeping genes as internal standards: use and limits. J Biotechnol 1999;75:291-295.

43 Livak KJ, Schmittgen TD: Analysis of relative gene expression data using real-time quantitative PCR and the 2(-Delta Delta C(T)) method. Methods 2001;25:402-408.

44 Heymsfield SB, Greenberg AS, Fujioka K, et al: Recombinant leptin for weight loss in obese and lean adults: a randomized, controlled, dose-escalation trial. JAMA 1999; 282:1568-1575.

45 Munzberg H, Myers MG Jr: Molecular and anatomical determinants of central leptin resistance. Nat Neurosci 2005;8:566-570.

46 Banks WA, Coon AB, Robinson SM, et al: Triglycerides induce leptin resistance at the blood-brain barrier. Diabetes 2004;53:12531260.

47 Kennedy AR, Pissios P, Otu H, et al: A highfat, ketogenic diet induces a unique metabolic state in mice. Am J Physiol Endocrinol Metab 2007;292:E1724-E1739.

48 Johnstone AM, Horgan GW, Murison SD, et al: Effects of a high-protein ketogenic diet on hunger, appetite, and weight loss in obese men feeding ad libitum. Am J Clin Nutr 2008;87:44-55.

49 Volek J, Sharman M, Gómez A, et al: Comparison of energy-restricted very low-carbohydrate and low-fat diets on weight loss and body composition in overweight men and women. Nutr Metab (Lond) 2004;1:13.

50 Yancy WS Jr, Olsen MK, Guyton JR, et al: A low-carbohydrate, ketogenic diet versus a low-fat diet to treat obesity and hyperlipidemia: a randomized, controlled trial. Ann Intern Med 2004;140:769-777.

51 Morens C, Sirot V, Scheurink AJ, van Dijk G: Low-carbohydrate diets affect energy balance and fuel homeostasis differentially in lean and obese rats. Am J Physiol Regul Integr Comp Physiol 2006;291:R1622-R1629.

52 Caton SJ, Yinglong B, Burget L, et al: Lowcarbohydrate high-fat diets: regulation of energy balance and body weight regain in rats. Obesity (Silver Spring) 2009;17:283289.

-53 Widdowson PS, Upton R, Pickavance L, et al: Acute hyperleptinemia does not modify insulin sensitivity in vivo in the rat. Horm Metab Res 1998;30:259-262. 